\title{
Autotetraploid Emergence via Somatic Embryogenesis in Vitis vinifera Induces Marked Morphological Changes in Shoots, Mature Leaves, and Stomata
}

\author{
Caterina Catalano ${ }^{1,+} \mathbb{D}$, Loredana Abbate ${ }^{1,+}{ }^{,}$, Antonio Motisi ${ }^{1}$, Dalila Crucitti ${ }^{1} \mathbb{D}$, Vincenzo Cangelosi ${ }^{2}$, \\ Antonino Pisciotta ${ }^{2}$,, Rosario Di Lorenzo ${ }^{2}$, Francesco Carimi ${ }^{1, *(\mathbb{D})}$ and Angela Carra ${ }^{1}$ \\ 1 Istituto di Bioscienze e BioRisorse, Consiglio Nazionale delle Ricerche, Corso Calatafimi 414, \\ 90129 Palermo, Italy; caterina.catalano@ibbr.cnr.it (C.C.); loredana.abbate@ibbr.cnr.it (L.A.); \\ antonio.motisi@ibbr.cnr.it (A.M.); dalila.crucitti@ibbr.cnr.it (D.C.); angela.carra@ibbr.cnr.it (A.C.) \\ 2 Dipartimento di Scienze Agrarie e Forestali, Università degli Studi di Palermo, Viale delle Scienze, Ed. 4, \\ 90128 Palermo, Italy; vincenzocangelosi03@gmail.com (V.C.); antonino.pisciotta@unipa.it (A.P.); \\ rosario.dilorenzo@unipa.it (R.D.L.) \\ * Correspondence: francesco.carimi@ibbr.cnr.it \\ + These authors have equally contributed to the study.
}

Citation: Catalano, C.; Abbate, L.; Motisi, A.; Crucitti, D.; Cangelosi, V.; Pisciotta, A.; Di Lorenzo, R.; Carimi,

F.; Carra, A. Autotetraploid

Emergence via Somatic

Embryogenesis in Vitis vinifera Induces Marked Morphological Changes in Shoots, Mature Leaves, and Stomata. Cells 2021, 10, 1336.

https://doi.org/10.3390/cells10061336

Academic Editor:

Suleyman Allakhverdiev

Received: 27 April 2021

Accepted: 24 May 2021

Published: 28 May 2021

Publisher's Note: MDPI stays neutral with regard to jurisdictional claims in published maps and institutional affiliations.

Copyright: (c) 2021 by the authors. Licensee MDPI, Basel, Switzerland. This article is an open access article distributed under the terms and conditions of the Creative Commons Attribution (CC BY) license (https:// creativecommons.org/licenses/by/ $4.0 /)$.
Abstract: Polyploidy plays an important role in plant adaptation to biotic and abiotic stresses. Alterations of the ploidy in grapevine plants regenerated via somatic embryogenesis (SE) may provide a source of genetic variability useful for the improvement of agronomic characteristics of crops. In the grapevine, the SE induction process may cause ploidy changes without alterations in DNA profile. In the present research, tetraploid plants were observed for $9.3 \%$ of 'Frappato' grapevine somatic embryos regenerated in medium supplemented with the growth regulators $\beta$-naphthoxyacetic acid $(10 \mu \mathrm{M})$ and $\mathrm{N}^{6}$-benzylaminopurine $(4.4 \mu \mathrm{M})$. Autotetraploid plants regenerated via SE without detectable changes in the DNA profiles were transferred in field conditions to analyze the effect of polyploidization. Different ploidy levels induced several anatomical and morphological changes of the shoots and mature leaves. Alterations have been also observed in stomata. The length and width of stomata of tetraploid leaves were 39.9 and $18.6 \%$ higher than diploids, respectively. The chloroplast number per guard cell pair was higher (5.2\%) in tetraploid leaves. On the contrary, the stomatal index was markedly decreased (12\%) in tetraploid leaves. The observed morphological alterations might be useful traits for breeding of grapevine varieties in a changing environment.

Keywords: autopolyploidy; molecular analysis; ploidy variability; somatic embryogenesis; stomatal characteristics; grapevine

\section{Introduction}

The possession of three or more complete sets of chromosomes is known as polyploidy and plays a crucial role in plant variation and evolution [1]. Whole genome duplication (WGD) is a major driver of adaptation, is responsible for angiosperm evolution [2], and is often a key factor in successful crop domestication [3]. Recent studies show physiological effects of WGD associated with increased dehydration stress tolerance in first-generation autotetraploids [4,5]. Moreover, a population genetic theory predicts both short- and longterm advantages of polyploidy [6]. Polyploidization is an important source of variability, with positive or negative outcomes [7], and is generally associated with increments of plant organs and alterations in stomatal density and size [8-14]. Polyploidization is also associated with an increase in tolerance and resistance to biotic [15] and abiotic stresses, such as salt and drought stresses [16-22].

Somatic embryogenesis (SE) is the induction of embryo generation from differentiated plant cells and it is an in vitro technique commonly used for clonal plant regeneration. The regeneration of somatic embryos in vitro has been used in a variety of applications such as 
virus elimination, cryopreservation, induced mutagenesis, and genetic engineering [23]. Tissue culturing is a source of stress for cells. Past studies revealed that regenerants obtained by in vitro cultures show genetic and epigenetic variations. This phenomenon was first described by Larkin and Scowcroft in 1981 [24], and was termed somaclonal variation. Therefore, in vitro clonal regeneration poses a problem of genetic stability [25]. On the other hand, it may represent an important source of novel variation. In some cases, plantlets regenerated in vitro through somatic embryogenesis may display chromosomal alterations and ploidy change, among other effects [26].

The grapevine (Vitis vinifera L.) is one of the most economically important woody crops cultivated worldwide, and more than 7000 cultivars are believed to exist around the world. So far, somatic embryos have been regenerated from different species of $\mathrm{Vi}$ tis [23], and new plants bearing specific characteristics (virus-free, normally developed, and genetically true-to-type) have been obtained using a wide range of organs and tissues as explant source $[27,28]$. One of the most common starting tissues is anthers [29] but SE has also been obtained from ovaries, stigmas, and styles [30], anther filaments [31], and whole flowers [32]. Less commonly, tendrils, leaf disks, leaves, petioles, and stem nodal explants have been used for somatic embryogenesis induction [33]. In the grapevine, the SE induction process may cause DNA alterations [34] which can give rise to a large set of variants both in table and wine cultivars [35], providing a source of genetic variability useful for the improvement of agronomic characteristics of plants. A few cases in the literature report the occurrence of spontaneous ploidy change emergence via SE in the grapevine [36,37], however the effects of polyploidization on plants are not reported.

Different approaches are used to evaluate the genetic stability of grapevine plants regenerated from somatic embryos. Phenotypic identification of somaclonal variation can be evaluated based on the observation of morphological and physiological traits, using the descriptors from the Organization of Vine and Wine [38]. However, some changes obtained after in vitro culture cannot be observed in planta, because differences that influence the biological activity may not affect the phenotype [39]. The molecular basis of genetic variations such as transcription, transposed elements, chromosomal rearrangements, gene amplifications and gene mutations is now known [40] and molecular markers have become an important tool to check genetic uniformity. Among the DNA-based markers, random amplified polymorphic DNA (RAPD), inter simple sequence repeat (ISSR), and simple sequence repeat (SSR) have been used for the determination of genetic fidelity [41]. Flow cytometric analysis (FCM) is considered one of the most effective techniques to detect ploidy changes in plants regenerated in vitro and has been successfully applied to verify ploidy levels in several species. FCM does not require rapidly dividing cells, and sample preparation requires only a small amount of tissue [41-43]. This technique is based on the use of DNA-specific fluorochromes and on the analysis of the relative fluorescence of stained nuclei [44].

In the present study, the incidence of autotetraploid in somatic embryos of the grapevine was evaluated as polyploid breeding can be very useful for improving specific traits such as quality, yield, or environmental adaptation. In addition, we analyzed the polyploidization effects on several anatomical/morphological characters using 15 descriptors from the Organization of Vine and Wine (OIV) and six quantitative parameters regarding morphological characteristics of mature leaves.

\section{Materials and Methods}

\subsection{Plant Material}

Three varieties used for wine production were utilized in the present study, namely 'Catarratto', 'Frappato', and 'Nero d'Avola' [45,46]. The plant material was collected from the germplasm repository for perennial plants at the Institute of Biosciences and BioResources of the National Research Council of Italy (CNR-IBBR) located in Collesano district (province of Palermo), Italy $\left(37^{\circ} 59^{\prime} 19.9^{\prime \prime} \mathrm{N}, 13^{\circ} 54^{\prime} 55.8^{\prime \prime} \mathrm{E}, 80 \mathrm{~m}\right.$ a.s.l.). Different 
floral explants (pistil, anther / filament, and ovary) used for culture initiation were dissected from flowers harvested 15 days before anthesis.

\subsection{Media and Culture Conditions and Plant Acclimatization}

Explants were cultured on MS solid (6 g/L plant agar) medium [47] under three different plant growth regulator (PGR) combinations: (1) VV-4 medium, $5 \mu \mathrm{M} N$-(2-chloro4-pyridyl)-N-phenylurea (4-CPPU) + $5 \mu \mathrm{M}$ 2,4-dichlorophenoxy acetic acid (2,4-D); 2) VV-5 medium, $20 \mu \mathrm{M} \beta$-naphthoxyacetic acid (NOA) $+4 \mu \mathrm{M} N$-phenyl- $N^{\prime}-1,2,3$-thiadiazol5-ylurea (TDZ); and (3) VV-16 medium, $10 \mu \mathrm{M} \mathrm{NOA}+4.4 \mu \mathrm{M}$ N6-benzylaminopurine (BA) [48]. Media were supplemented with $88 \mathrm{mM}$ sucrose. The $\mathrm{pH}$ of the media was adjusted to 5.7-5.8 with $1 \mathrm{~N} \mathrm{NaOH}$ before autoclaving. All chemicals were purchased from Duchefa Biochemie, Netherland. Explants were incubated in a climatic chamber at $26{ }^{\circ} \mathrm{C}$ with a $16 \mathrm{~h}$ photoperiod $\left(40 \mu \mathrm{mol} \mathrm{m} \mathrm{m}^{-2} \mathrm{~s}^{-1}\right.$ at shelf level, provided by Osram Cool White $18 \mathrm{~W}$ fluorescent lamps) and subcultured in the same culture medium at $60 \mathrm{~d}$ intervals. The explants showing embryogenic responses were transferred to basal MS-medium-deprived PGRs, supplemented with $88 \mathrm{mM}$ sucrose and cultured for four more weeks to allow embryo proliferation and development. Then, germinated somatic embryos were collected and individually transferred to Magenta ${ }^{\mathrm{TM}}$ vessels containing $100 \mathrm{~mL}$ of basal solid MS medium under the same light and temperature conditions as described above, to allow further growth. After rooting, four plants produced from each somatic embryo $(10-15 \mathrm{~cm})$ were transferred to autoclaved Jiffy-7 peat pellets and moved onto a heating bench at $25^{\circ} \mathrm{C}$ and high relative humidity (95-98\%). After 4-5 weeks, plants were transferred into $2 \mathrm{~L}$ pots containing sterilized soil under natural daylight at $22 / 27^{\circ} \mathrm{C}$ (night/day). After acclimatization, plantlets were transferred to the greenhouse located in Collesano district, grown in $20 \mathrm{~L}$ pots on a composite substrate of $2 / 3$ peat and $1 / 3$ agriperlite and fertilized with full strength nutrient solution as described by Oddo et al. [49]. After a 30-40-day period of acclimatization in the greenhouse the plants were transferred to field conditions for assessment of ampelographic traits.

\subsection{Flow Cytometry Analysis}

The DNA content was evaluated by FCM according to Carra et al. [50]. A total of 88 plantlets regenerated from somatic embryos were used and compared with the meristem tips of mother plants. The analysis was carried out with the Partec PAS flow cytometer (Partec GmbH, Munster, Germany), equipped with a mercury lamp. Fully expanded and young leaves $(0.01 \mathrm{~g})$ were chopped in a glass Petri dish with $1 \mathrm{~mL}$ nuclei extraction OTTO buffer 1 [51] and three drops of Tween 20. After $3 \mathrm{~min}, 1 \mathrm{~mL}$ of OTTO buffer 2 [51] was added. In addition, PVP-10 (1\%) was added to plant samples to neutralize interference by cell metabolites in the analysis. The solution was filtered through a $30 \mu \mathrm{m}$ Cell-Trics disposable filter Partec, and $400 \mu \mathrm{L}$ of staining solution containing 4,6-diamidino-2-phenylindole (DAPI) was added. Routinely, 3000-4000 nuclei for each sample were measured, and histograms of DNA content were generated using the Partec software package (FloMax). Three replicates for each sample were carried out. The fluorescence intensity emitted was normalized by isolated nuclei from Pisum sativum L., optimal DNA reference standard for plant cytometric analyses [52]. This calibration was checked periodically.

\subsection{Assessment of Genetic Stability in Regenerants by RAPD, ISSR, and SSR Markers}

Regenerants coming from different embryogenic events, randomly chosen from three different explants cultured on different media, were compared to the mother plant for evaluation of genetic stability. Plant DNA was isolated from fresh leaves $(100 \mathrm{mg})$ using the cetyltrimethylammonium bromide (CTAB) method as described by Doyle and Doyle [53]. The isolated genomic DNA was used for RAPD and ISSR analyses in order to assess mutations (Supplementary Table S1). The RAPD analysis of the grapevine genotypes was performed using eight random decamer primers-OPAT14, OPH15, OPM04, UBC219, UBC234, UBC239, UBC247, and UBC251 [54,55]. Seven ISSR primers-UBC834, 
UBC841, UBC848, UBC851, UBC855, ENEA7-9, and ENEA12 were used to amplify the genomic DNA $[41,48,50]$. For both molecular markers, polymerase chain reaction (PCR) amplification and analysis were performed as described by Carra et al. [48]. Only in those cases where the flow cytometry histograms revealed that the ploidy level of regenerated plants was different from that of the mother plant, an additional set of seven ISSR and nine simple sequence repeats (SSR) was tested for more accurate genetic stability evaluation. The additional ISSR analysis was carried out with ISSR $2+2 \mathrm{~b}\left((\mathrm{AC})_{8} \mathrm{YG}\right.$; Ta $\left.49^{\circ} \mathrm{C}\right)$, ISSR $3+$ $3 \mathrm{~b}\left((\mathrm{AG})_{8} \mathrm{YC}\right.$; Ta $\left.49^{\circ} \mathrm{C}\right)$, ISSR $11+11 \mathrm{~b}\left((\mathrm{GA})_{8} \mathrm{YC}\right.$; Ta $\left.56{ }^{\circ} \mathrm{C}\right)$, ISSR1-6 $\left((\mathrm{CA})_{8} \mathrm{RG}\right.$; Ta $\left.49^{\circ} \mathrm{C}\right)$, ENEA21 ((GA) ${ }_{8} \mathrm{GG}$; Ta $\left.49^{\circ} \mathrm{C}\right)$, ENEA34 ((ACC) 6 CC; Ta $\left.52^{\circ} \mathrm{C}\right)$, and ENEA36 (CC(ATG) 6 ; Ta $\left.56^{\circ} \mathrm{C}\right)[41,56,57]$. SSR analysis was carried out using nine primer pairs-VVMD7, VVMD24, VVMD25, VVMD27, VVIb01, VVIh54, VVIp31, VVIp60, and VVIq52, distributed homogenously along the 19 chromosomes of diploid genome (475 Mbp and $2 n=38$ chromosomes) of the grapevine (Supplementary Table S1). The SSR-PCR reactions were followed as described by De Michele et al. [58]; amplicons of each primer on all individuals were scored by an external service (Eurofins Genomics, Germany), and SSR allelic size was determined using the Gene Mapper v. 5.0 software. To confirm the reproducibility of the banding patterns, all analyses were repeated twice.

\subsection{Ampelographic Analysis}

Plants were phenotypically evaluated by morphological analysis of 15 descriptors from the Organization of Vine and Wine [38], relative to shoots and mature leaves (Table 1). Plant material for ampelographic analysis was collected in May (shoots) and July (leaves). The observations were performed on 15 fully expanded leaves (from the third node of several shoots) and 10 shoot tips for each embryogenic event.

Table 1. Ampelographic characteristics of $2 n$ and $4 n$ regenerants based on the 15 OIV descriptors used (OIV, 2009).

\begin{tabular}{|c|c|c|c|c|c|}
\hline OIV Code & OIV Descriptor & Levels & 2n (E51) & $4 n(E 33)$ & $4 n(E 34)$ \\
\hline OIV 001 & $\begin{array}{l}\text { Young shoot: opening of the } \\
\text { shoot tip }\end{array}$ & (1) Closed; (3) half open; (5) fully open & 1 & 5 & 5 \\
\hline OIV 007 & $\begin{array}{l}\text { Shoot: color of the dorsal } \\
\text { side of internodes }\end{array}$ & (1) Green; (2) green and red; (3) red & 2 & 2 & 2 \\
\hline OIV 008 & $\begin{array}{l}\text { Shoot: color of the ventral } \\
\text { side of internodes }\end{array}$ & (1) Green; (2) green and red; (3) red & 2 & 2 & 2 \\
\hline OIV 065 & Mature leaf: size of blade & $\begin{array}{l}\text { (1) Very small; (3) small; (5) medium; (7) } \\
\text { large; (9) very large }\end{array}$ & 3 & 5 * & $7 *$ \\
\hline OIV 067 & Mature leaf: shape of blade & $\begin{array}{l}\text { (1) Cordate; (2) wedge-shaped; (3) } \\
\text { pentagonal; (4) circular; (5) } \\
\text { kidney-shaped }\end{array}$ & 3 & 3 & 3 \\
\hline OIV 068 & $\begin{array}{l}\text { Mature leaf: number } \\
\text { of lobes }\end{array}$ & $\begin{array}{l}\text { (1) One (entire leaf); (2) three; (3) five; (4) } \\
\text { seven; (5) more than seven }\end{array}$ & 3 & 2 & 2 \\
\hline OIV 072 & $\begin{array}{l}\text { Mature leaf: goffering } \\
\text { of blade }\end{array}$ & $\begin{array}{l}\text { (1) Absent or very weak; (3) weak; (5) } \\
\text { medium; (7) strong; (9) very strong }\end{array}$ & $\underline{1}$ & $\underline{1}^{*}$ & $3 *$ \\
\hline OIV 074 & $\begin{array}{l}\text { Mature leaf: profile of blade } \\
\text { in cross section }\end{array}$ & $\begin{array}{l}\text { (1) Flat; (2) V-shaped; (3) involute; 4) } \\
\text { revolute; (5) twisted }\end{array}$ & 1 & 2 & 2 \\
\hline OIV 075 & $\begin{array}{l}\text { Mature leaf: blistering of } \\
\text { upper side of blade }\end{array}$ & $\begin{array}{l}\text { (1) Absent or very weak; (3) weak; (5) } \\
\text { medium; (7) strong; (9) very strong }\end{array}$ & 1 & 3 & 3 \\
\hline OIV 076 & Mature leaf: shape of teeth & $\begin{array}{l}\text { (1) Both sides concave; (2) both sides } \\
\text { straight; ( } 3 \text { ) both sides convex; (4) one } \\
\text { side concave, one side convex; }(5) \\
\text { mixture between, both sides straight and } \\
\text { both sides convex }\end{array}$ & $\underline{4}$ & $5 *$ & $\underline{4}^{*}$ \\
\hline OIV 078 & $\begin{array}{l}\text { Mature leaf: length of teeth } \\
\text { compared with their width }\end{array}$ & $\begin{array}{l}\text { (1) Very short; (3) short; (5) medium; (7) } \\
\text { long; (9) very long }\end{array}$ & 3 & $5 *$ & $7^{*}$ \\
\hline
\end{tabular}


Table 1. Cont.

\begin{tabular}{|c|c|c|c|c|c|}
\hline OIV Code & OIV Descriptor & Levels & 2n (E51) & 4n (E33) & 4n (E34) \\
\hline OIV 079 & $\begin{array}{c}\text { Mature leaf: degree of } \\
\text { opening/overlapping of } \\
\text { petiole sinuses }\end{array}$ & $\begin{array}{l}\text { (1) Very wide open; (3) open; (5) closed; } \\
\text { (7) overlapped; (9) strongly overlapped }\end{array}$ & 3 & 7 & 7 \\
\hline OIV 082 & $\begin{array}{l}\text { Mature leaf: degree of } \\
\text { opening/overlapping of } \\
\text { upper lateral sinuses }\end{array}$ & $\begin{array}{l}\text { (1) Open; (2) closed; (3) slightly } \\
\text { overlapped; (4) strongly overlapped; (5) } \\
\text { absence of sinus }\end{array}$ & 1 & 5 & 5 \\
\hline OIV 093 & $\begin{array}{l}\text { Mature leaf: length of } \\
\text { petiole compared to length } \\
\text { of middle vein }\end{array}$ & $\begin{array}{l}\text { (1) Much shorter; (3) slightly shorter; (5) } \\
\text { equal; (7) slightly longer; (9) much longer }\end{array}$ & $3(0.72)$ & $1(0.56)$ & $1(0.59)$ \\
\hline OIV 094 & $\begin{array}{l}\text { Mature leaf: depth of upper } \\
\text { lateral sinuses }\end{array}$ & $\begin{array}{l}\text { (1) Absent or very shallow; (3) shallow; } \\
\text { (5) medium; (7) deep; (9) very deep }\end{array}$ & 5 & 1 & 1 \\
\hline
\end{tabular}

Identical characteristics among all samples are in bold. The asterisk $\left(^{*}\right)$ indicates the values different between the two tetraploid plants. The underlined values refer to identical characteristics observed between a diploid and a tetraploid, which is in turn different from the other tetraploid.

\subsection{Stomatal Characteristics}

The effect of different ploidy levels on regenerants was also investigated by morphological analysis of mesophyll epidermal structures under light microscopy. Mature leaves were used to analyze six quantitative parameters regarding morphological characteristics of diploid and tetraploid regenerants as reported in Table 2. A few strips of epidermis were torn from the abaxial side of fully expanded leaves from diploid and tetraploid plants. Tissue segments were mounted on a microscope slide with a drop of distilled water and a coverslip to measure stomata size. The sizes of 20 stomata for each sample were evaluated under a light microscope (Optech Biostar BM 45 trinocular microscope with a Tucsen ISH 300 digital camera). Immediately after the preparation, the number of chloroplasts in the two guard cells of the same stomata was counted directly from microscope slide. Data were collected using ISCAPTURE Version 3.0. The stomatal index $(\mathrm{SI})$ was also measured as $(\mathrm{S} /(\mathrm{E}+\mathrm{S})) \times 100$, where $\mathrm{S}$ is the number of stomata and $\mathrm{E}$ is the number of epidermal cells per unit leaf area [59].

Table 2. Morphological comparison of diploid and tetraploid leaves.

\begin{tabular}{cccc}
\hline Characteristics & 2n (E51) & 4n (E33) & 4n (E34) \\
\hline Leaf length $(\mathrm{cm})$ & $8.4 \pm 0.7^{\mathrm{a}}$ & $9.5 \pm 1^{\mathrm{a}}$ & $9.5 \pm 0.5^{\mathrm{a}}$ \\
Leaf width $(\mathrm{cm})$ & $9.4 \pm 1.1^{\mathrm{a}}$ & $13 \pm 0.5^{\mathrm{b}}$ & $11.8 \pm 0.3^{\mathrm{b}}$ \\
Leaf area $\left(\mathrm{cm}^{2}\right)$ & $43.3 \pm 8.7^{\mathrm{a}}$ & $79.8 \pm 6.1^{\mathrm{b}}$ & $82.6 \pm 3.1^{\mathrm{b}}$ \\
Stomatal length $(\mu \mathrm{m})$ & $18.3 \pm 0.5^{\mathrm{a}}$ & $27.1 \pm 0.5^{\mathrm{b}}$ & $24.1 \pm 0.5^{\mathrm{b}}$ \\
Stomatal width $(\mu \mathrm{m})$ & $13.4 \pm 0.3^{\mathrm{a}}$ & $16.3 \pm 0.3^{\mathrm{b}}$ & $15.5 \pm 0.6^{\mathrm{b}}$ \\
Number of chloroplastsper & $44.3 \pm 2.8^{\mathrm{a}}$ & $47.1 \pm 2.6^{\mathrm{a}}$ & $46.1 \pm 2.6^{\mathrm{a}}$ \\
guard cell pair & $10.7 \pm 0.3^{\mathrm{a}}$ & $10.1 \pm 1.1^{\mathrm{b}}$ & $9.0 \pm 0.5^{\mathrm{b}}$ \\
SI &
\end{tabular}

Stomatal index (SI) values are also reported. Data represent mean \pm standard deviation $(n=10)$. Different lowercase letters within rows indicate a significant difference at the $5 \%$ level $(p<0.05)$.

\subsection{Statistical Analysis}

Experiments were performed in a randomized complete block design with 10 replicates (Petri dishes) per treatment. Five explants each for stigma/style and ovary and 25 explants for anther/filament were used per plate. The embryogenic response of explants, the effect of different culture media, and the effect of explant type were expressed as a percentage on a Petri-dish basis and recorded 6 months after explant incubation. Percentages of embryo germination were recorded 2 months from the incubation of somatic embryos on PGR-free medium. The percentage data were arcsine square-root transformed prior to analysis. The results were back-transformed and presented as mean \pm standard error. To highlight statistically significant differences and possible interactions between explant, 
medium, and genotype, the multi-way analysis of variance (ANOVA) was performed $(p \leq 0.05)$. One-way ANOVA was performed when the interaction between the factors was not significant. The separation of the averages was performed by Tukey's test $(p \leq 0.05)$.

For the molecular analysis, only bands showing consistent amplification within the range of $200 \mathrm{bp}$ to $3.5 \mathrm{~kb}$ were considered. Polymorphic ISSR and RAPD markers were scored for the presence (1) or absence (0) of bands for all the somaclones analyzed. All reactions were repeated at least twice, and only well-resolved, distinct, polymorphic, and reproducible bands across all runs were considered for analysis. Bands with the same migration were considered homologous fragments, independently of their intensity. Smeared DNA fragments and weak bands, which could not be readily distinguished, were excluded. In the SSR analysis, peak intensity was considered and compared with the internal size standard to estimate allele size as described by De Michele et al. [58]. For morphological evaluation, the data collected were subjected to statistical analysis using standard deviations of the mean and thereafter to ANOVA ( $p \leq 0.05)$. Prior to analysis, percentage data were arcsine square-root transformed. Statistical analysis was performed using SigmaStat 3.5 for Windows.

\section{Results}

\subsection{Somatic Embryogenesis}

Explants produced a white callus 10-30 days after culture initiation, and somatic embryos emerged from callus surface 100 days after culture initiation. Figure 1 shows the embryogenic responses after six months of culture initiation in different treatments tested in three cultivars. The embryogenic potential varied greatly (0-22\%) depending on explant type, genotype, and PGR combination used. The genotype was an important factor influencing plant regeneration. In fact, embryogenic capacity of the three cultivars (calculated across the media and explant types) ranged from $2.8 \%$ for 'Nero d'Avola' to 6.7\% for 'Frappato' (Table 3). Regarding explant type (Table 4$)$, pistils were more responsive $(5.7 \%)$ compared to ovary (3.6\%) and anther/filament (3.1\%). Somatic embryogenesis occurred under all the culture conditions tested, with no significant differences according to the treatment tested (Table 4). Embryo germination percentages of 'Frappato' (55\%), calculated across the medium and explant types, was lower than that of 'Catarratto' (63\%) and 'Nero d'Avola' (67\%). Plants maintained in vitro for 2 months after embryo germination reached an average height of $150 \mathrm{~mm}$, and these well-developed plantlets could be transferred to Jiffy-7 peat pellets.

Table 3. Genotype specificity of somatic embryogenesis.

\begin{tabular}{cc}
\hline Genotype & Embryogenic Explants (\%) \\
\hline 'Catarratto' & $2.9 \pm 0.2^{\mathrm{b}}$ \\
'Nero d'Avola' & $2.8 \pm 0.6^{\mathrm{b}}$ \\
'Frappato' & $6.7 \pm 0.7^{\mathrm{a}}$ \\
\hline
\end{tabular}

Somatic embryogenesis data were collected 6 months after culture initiation. Means + SE, values followed by the same letter are not significantly different at $p<0.05$ level (Tukey's test).

Table 4. Effect of three PGR combinations (VV-4, VV-5, and VV-16) and three explant types (ovary, pistil, and anther/filament) on somatic embryogenesis.

\begin{tabular}{cccc}
\hline Media & $\begin{array}{c}\text { Embryogenic } \\
\text { Explants (\%) }\end{array}$ & $\begin{array}{c}\text { Explant } \\
\text { Type }\end{array}$ & $\begin{array}{c}\text { Embryogenic } \\
\text { Explants (\%) }\end{array}$ \\
\hline VV-4 $(5 \mu \mathrm{M}$ CPPU $+5 \mu \mathrm{M} 2,4-\mathrm{D})$ & $3.6+0.2^{\mathrm{a}}$ & Ovary & $3.6+0.2^{\mathrm{b}}$ \\
VV-5 $(20 \mu \mathrm{M}$ NOA $+4 \mu \mathrm{M}$ TDZ $)$ & $4.2+0.3^{\mathrm{a}}$ & Pistil & $5.7+0.6^{\mathrm{a}}$ \\
VV-16 $(10 \mu \mathrm{M} \mathrm{NOA}+4.4 \mu \mathrm{M} \mathrm{BA})$ & $4.6+0.1^{\mathrm{a}}$ & Anther/filament & $3.1+0.2^{\mathrm{b}}$ \\
\hline
\end{tabular}

Data were collected 6 months after culture initiation. Means + SE, in each column's values followed from the same letter are not significantly different at $p<0.05$ level (Tukey's test). 


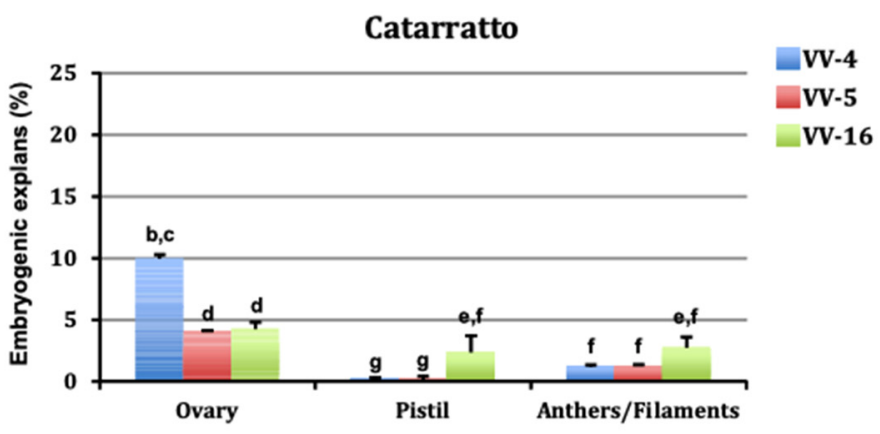

Nero d'Avola

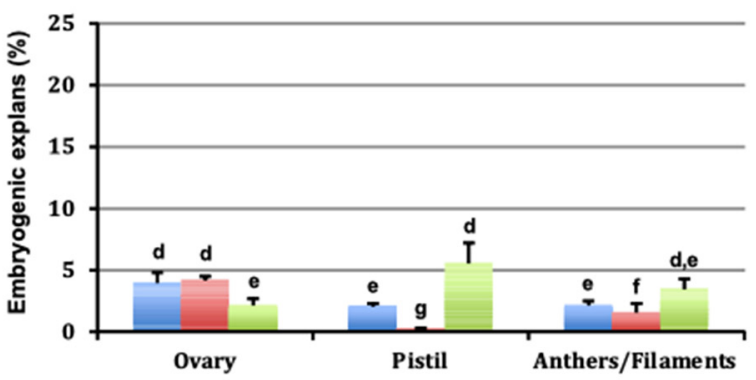

Frappato

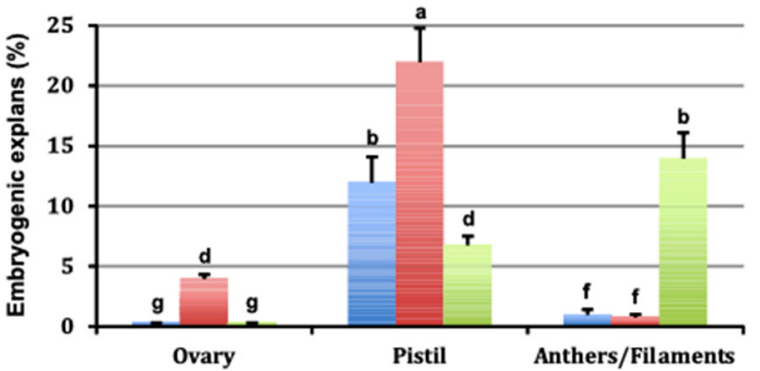

Figure 1. Percentages of embryogenic explants of 'Catarratto', 'Nero d'Avola', and 'Frappato' using three explant types and three PGR combinations. Data were collected 6 months after culture initiation and each treatment comprised 250 explants for anthers/filaments and 50 explants for ovaries and pistils. Means \pm SE, values followed by the same letter are not significantly different at $p<0.05$ level (Tukey's test).

\subsection{Ploidy Analysis}

The ploidy level of regenerated plants was evaluated by FCM analysis by comparing nuclear DNA contents of the regenerants and the respective mother plant. A total of 31 regenerants of 'Frappato', 32 of 'Catarratto', and 25 of 'Nero d'Avola' were analyzed. The histograms revealed that the ploidy levels of most regenerated plants were the same as that of the mother plant (diploid, Figure 2A). However, different ploidy levels (tetraploid, Figure 2B) were detected in three (events 22, 33, and 34) 'Frappato' regenerated plants (9.3\% of regenerants), all obtained in NOA $(10 \mu \mathrm{M})$ and BA $(4.4 \mu \mathrm{M})$ supplemented medium (VV-16) from pistil explants. 
A

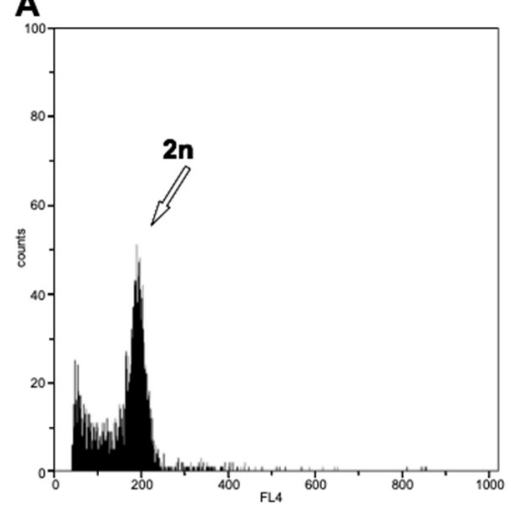

C

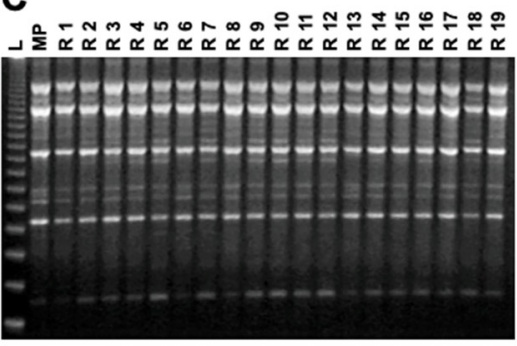

B

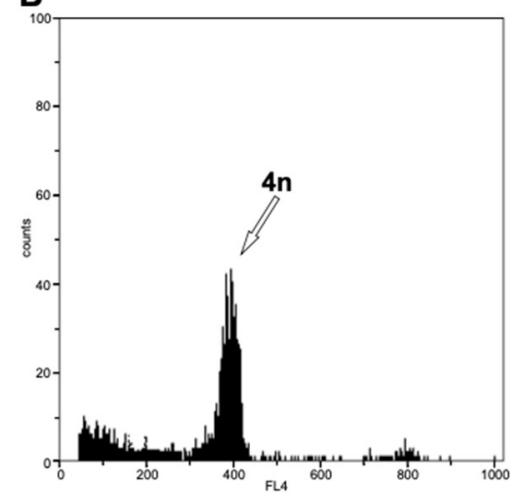

D

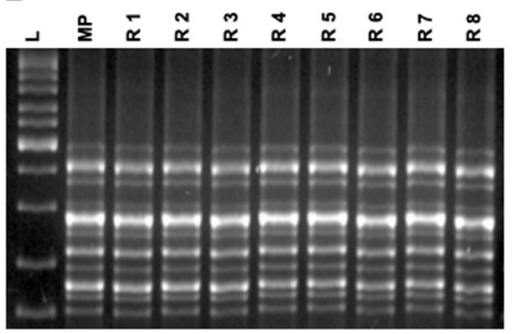

Figure 2. Ploidy level and genetic stability of regenerants through flow cytometric analysis and ISSR markers. Representative flow cytometric histograms of nuclei isolated from leaves of diploid $((\mathbf{A})=$ event 51) and tetraploid plants $((\mathbf{B})=$ event 34$)$. Histograms showed the fluorescence intensity of diploids on channel 200 and that of tetraploids on channel 400. The data were obtained with the same instrument setting. The gain was positioned on channel 200 for diploid nuclei, while tetraploid nuclei peak appeared on channel 400. (C) DNA profiles of 'Frappato' regenerants amplified with the RAPD primer OPAT-14. L, ladder 123-bp; MP, mother plant; R 1-19, in vitro regenerants. (D) Genetic fidelity assessment of 'Frappato' regenerants with ISSR marker (ENEA7-9). L, ladder Thermo Scientific ${ }^{\mathrm{TM}}$ GeneRuler ${ }^{\mathrm{TM}}$ DNA Ladder Mix; MP, mother plant; R 1-8, in vitro regenerants. Amplification profiles were monomorphic across all regenerants.

\subsection{Assessment of Genetic Stability in Regenerants by RAPD, ISSR, and SSR Markers}

To assess the genetic status of the progeny resulting from somatic embryogenesis, mother plants and regenerants were characterized by RAPD, ISSR, and SSR markers. The eight RAPD primers generated bands ranging from 200 to $3100 \mathrm{bp}$ in size (Supplementary Table S1). The number of bands in the selected primers varied from 4 (UBC234) to 8 (OPAT14 and OPH15), with an average of 6.25 bands per RAPD primer. The 14 ISSR markers analyzed generated amplicons ranging from 300 to $3500 \mathrm{bp}$ in size (Supplementary Table S1). The number of bands for each primer varied from 4 (ISSR2 $+2 b)$ to 11 (ENEA7-9), with an average of approximately 7 bands per ISSR primer.

Both RAPD and ISSR analysis revealed homogeneity among regenerated plants and the in-vitro-obtained plants of the same cultivar (Figure 2C-D). No changes in the DNA profiles were detected by the additional set of seven ISSR showing monomorphic bands between tetraploid and diploid regenerants (Figure 3A,B).

Of nine SSR primer pairs used to compare the genetic stability between the three tetraploid plants of 'Frappato' and their mother plant (Supplementary Table S1), six SSRs revealed the presence of two alleles per locus in regenerants, as in the mother plant profiles (SSR profiles generated by marker VVMD27 are reported in Figure 3C). SSR profiles were also generated and the value of the size for each SSR locus were the same between the regenerants and the mother plant, confirming the genetic homogeneity through SSR marker-based DNA fingerprinting. 
A

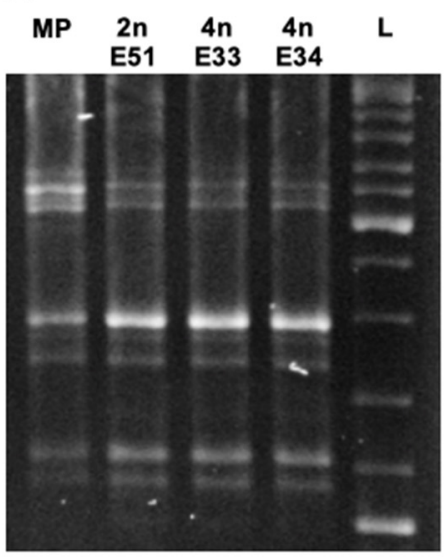

C

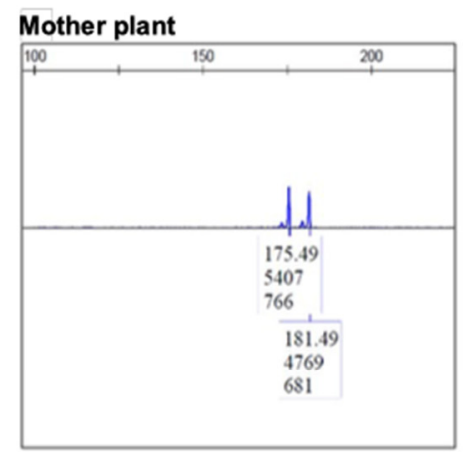

Event 33 (4n)

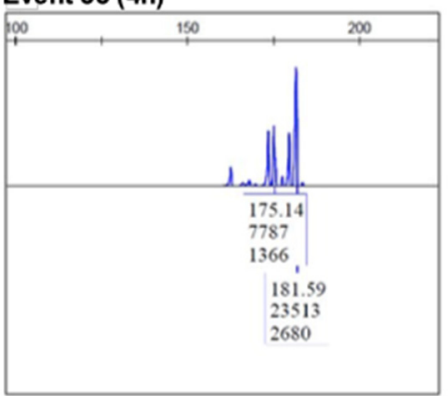

B

MP 2n 4n 4n L
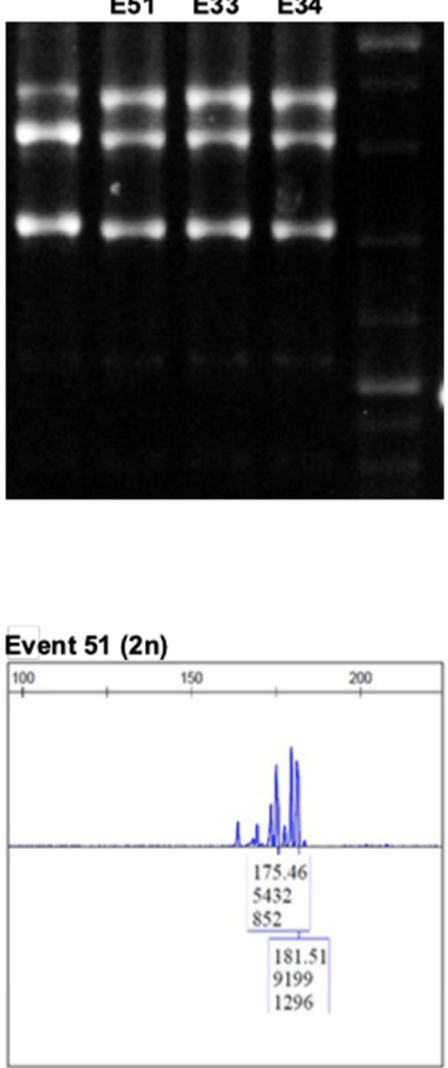

Event 34 (4n)

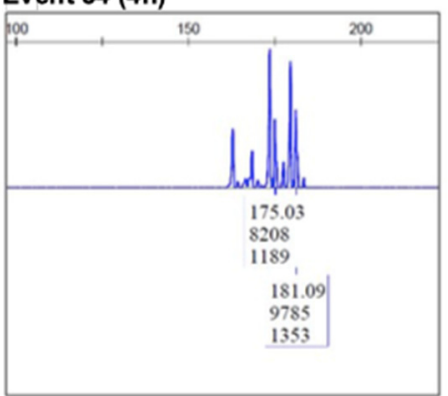

Figure 3. Genetic fidelity assessment of diploid (event 51) and tetraploid (events 33 and 34) 'Frappato' regenerants with ISSR markers. Profiles were obtained with: (A) Primer ISSR1-6; L, ladder Thermo Scientific $^{\mathrm{TM}}$ GeneRuler ${ }^{\mathrm{TM}}$ DNA Ladder Mix; MP, mother plant; E51, event 51 (2n); E33, event 33 (4n); E34, event 34 (4n). (B) Primer ISSR2 + 2b. L, ladder Thermo Scientific ${ }^{\mathrm{TM}}$ GeneRuler $^{\mathrm{TM}}$ DNA Ladder Mix; MP, mother plant; E51, event 51 (2n); E33, event 33 (4n); E34, event 34 (4n). Amplification products were monomorphic across all regenerants. (C) SSR profiles generated by SSR marker VVMD27 of 'Frappato' mother plant, event 51 (2n), event 33 (4n), and event 34 (4n).

\subsection{Ampelographic Analysis}

To determine the influence of ploidy on morphological changes, diploid and tetraploid plants of 'Frappato' generated from different embryogenic events were analyzed. The vegetative behavior of diploid and tetraploid regenerants was assessed 4 years after acclimatization to overcome the juvenility phase. Phenotypes appeared homogeneous in all the diploid lines analyzed and therefore the diploid event N51 was chosen as a representative diploid plant for subsequent analyses. The plants derived from one of the tetraploid embryos did not survive and were therefore excluded from ampelographic analyses. To test the influence of the ploidy variation on morphological changes, a diploid (event N51) and two tetraploids (events N33 and N34, survived to ex vitro condition) regenerated 
plants were analyzed. The results of the ampelographic comparison between diploid and tetraploid events are reported in Table 1. The descriptions from the present study show that the diploid and tetraploid regenerants shared three (OIV 007, 008, and 067) out of 15 traits (in bold in Table 1), two of them regarding the shoot and one the mature leaf. The two tetraploid regenerants shared 11 out of 15 traits (underlined in Table 1), eight of them relative to mature leaf morphology and three to shoot. For example, the young shoot tip (OIV1) was fully open in tetraploid plants and closed in diploid ones (Table 1; Figure $4 \mathrm{~A}-\mathrm{C})$. Also, the leaf morphology varied significantly between the tetraploid and diploid plants (Figure 4D-N). Only in four cases (asterisk in Table 1) did the two tetraploid forms differ from each other (OIV 065, 072, 076, and 078), yet for two traits (OIV 072 and 076) one of the two tetraploid plants was similar to the diploid (underlined in Table 1).
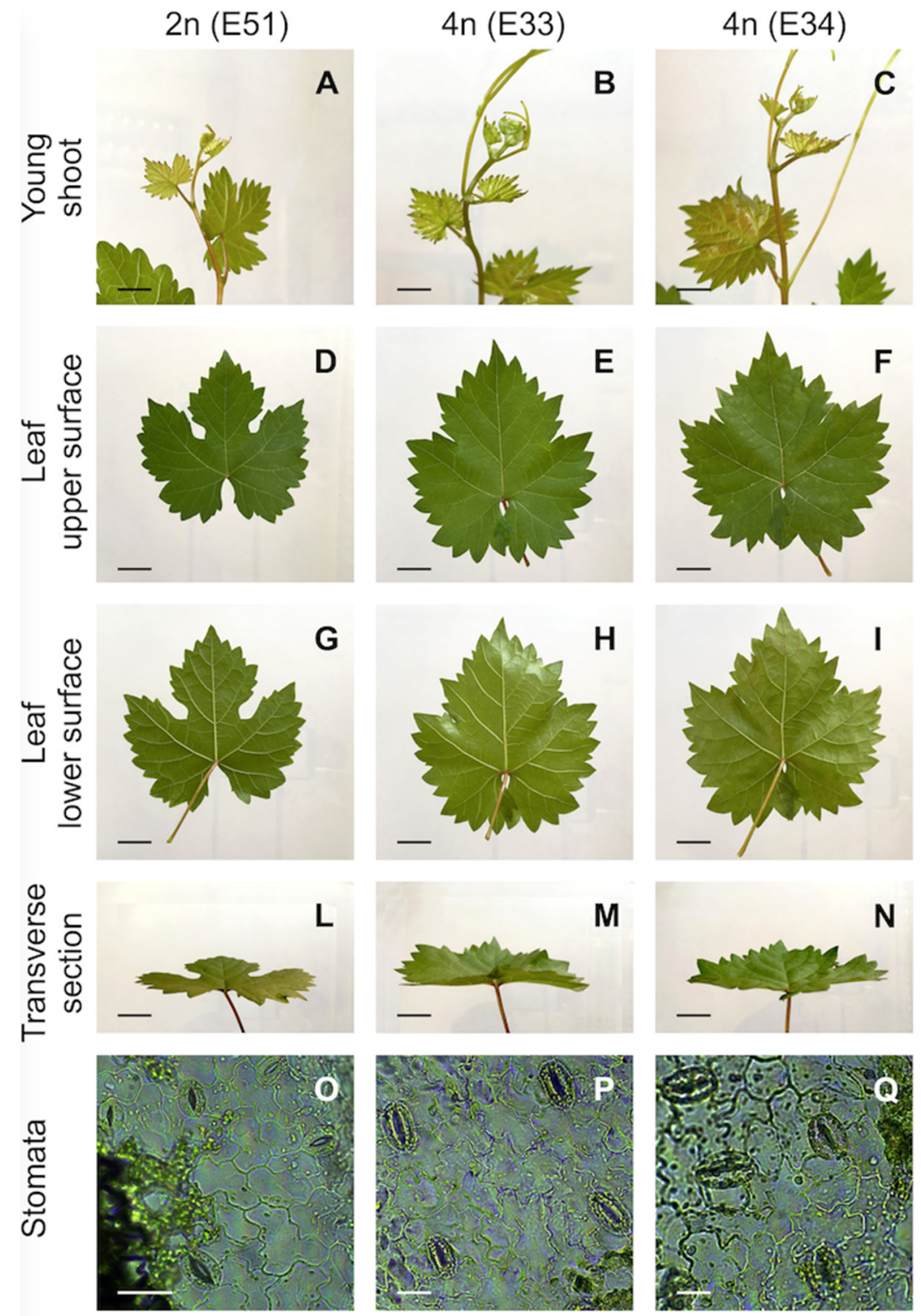

Figure 4. Morphological changes of the shoots, mature leaves, and stomata of diploid (event 51) and tetraploid (events 33 and 34) regenerants. $(\mathbf{A}-\mathbf{C})$ Young shoot $($ bar $=1.5 \mathrm{~cm}) ;(\mathbf{D}-\mathbf{F})$ mature leaves upper surface $($ bar $=2 \mathrm{~cm})$; $(\mathbf{G}-\mathbf{I})$ mature leaves lower surface $($ bar $=2 \mathrm{~cm}) ;(\mathbf{L}-\mathbf{N})$ mature leaves transverse section $(\mathrm{bar}=2 \mathrm{~cm})$; and $(\mathbf{O}-\mathbf{Q})$ stomata in mature leaves $(\mathrm{bar}=20 \mu \mathrm{m})$. 


\subsection{Leaf Morphological Characteristics and Stomata}

The morphological characteristics of tetraploid grapevine leaves differed from those of the diploid counterparts (Table 2). Leaves of tetraploids were larger and longer than those of diploid ones. Compared with the diploid leaves, width and area of tetraploids were 31.9 and $87.5 \%$ higher, respectively (Table 2 ).

The stomata of tetraploid leaves were larger and longer that those of diploid ones (Table 2; Figure 4O-Q). The length and width of stomata of tetraploid leaves were 39.9 and $18.6 \%$ greater, respectively, than those of diploid leaves. The chloroplast number per guard cell pair was similar in tetraploid and diploid leaves. The SI was significantly lower in the two tetraploids (9.0 and 10.1) than in the diploid form (10.7) (Table 2).

\section{Discussion}

Polyploidization is a powerful strategy for genetic improvement and a successful method for inducing relevant physiological and morphological variations in plants [60]. Polyploidization events are associated with significant effects on plant anatomy and morphology. The volume of tetraploid cells is usually twice as high compared with that of diploid cells [61] and, as a consequence, the size of organs increases. Tetraploid plants often bear favorable horticultural traits, such as a larger fruits, sturdiness, high productivity, and tolerance to biotic and abiotic stresses [20,62]. Somatic embryogenesis is an efficient technique for clonal propagation; nevertheless, regenerated plants may exhibit somaclonal variations [24]. The rate of somaclonal variations is influenced by several stress factors such as wounding, exposure to sterilizing agents, plant growth regulators, sugar, or light conditions and can be particularly high when a callus phase or secondary embryogenesis is present [63]. The results reported in this paper show that grapevine plants regenerated via somatic embryogenesis may lead to somaclonal variations. Tetraploid plants have been obtained starting from floral explants cultivated in the presence of NOA and BA in one genotype, among the three genotypes analyzed. Several papers describe successful selections of somaclonal variants with a wide range of improved traits such as resistance to pests, diseases, and herbicides [64]. Somaclonal variation can also be considered as a tool for inducing ameliorative variations, as reported for several crops such as hazel nut [65], ray [66], Citrus paradisi [67], oil palm [68], potato [69], coffee [70], olive [71], and sugarcane [72]. In the grapevine, somaclonal variation can be spontaneous or induced [73]. Some mutated traits have been described in plants regenerated from nucellar tissue culture in vitro, such as reduction in the size of the berries, a decrease in yield of about $50 \%$, and a marked increase in the sugar content [74]. Mutated individuals obtained with our experimental procedure showed morphological differences in shoots, mature leaf shape, and stomata characteristics. Ampelographic analysis showed markedly different phenotypes between diploid and tetraploid forms, with 12 out of 15 traits diverging. Conversely, comparison of OIV descriptors showed a similar phenotype in all the tetraploid regenerants, which shared $80 \%$ of traits, with very minor discrepancies. Their similarity is also confirmed by the biometric analysis of the mature leaves, which were significantly larger in the two tetraploid lines than in diploids. The variability in leaf morphology, i.e., the degree of opening of petiole and lateral sinuses, the number of lobes, the undulations or blistering of the blade, and the goffering and the profile of the blade in a cross section, may influence the mechanisms of the responses of plants to external stimuli, such as disease resistance [75]. We observed that stomata dimension and density are influenced by polyploidization, being larger in size and less numerous in tetraploids. This characteristic can affect infections, as stomata are one of the major portals for pathogen penetration [76]. Studies carried out on several grapevine varieties reported a positive correlation between susceptibility to downy mildew and stomatal density [75].

A callus phase during the initial stages of the regeneration pathway can facilitate the onset of chromosomal alterations and changes in the ploidy level [77]. Since in our culture conditions, during culture initiation, a callus phase was detected, the genetic stability of regenerants was verified. Somaclonal variants can be identified using different 
techniques both for morphological and molecular traits. Flow cytometry has been used in the grapevine to verify the ploidy level and ploidy stability of somatic embryogenesisderived plants [36,39]; flow cytometry can easily and accurately distinguish tetraploid from diploid plants. However, in the grapevine the high number and the reduced dimension of the chromosomes $(2 n=38)$ make karyotyping an inconclusive strategy. Moreover, cytosolic phenolics, such as tannic acid, negatively influence flow cytometry results [39]. Our procedure presents several ameliorative aspects: a detergent and PVP-10 have been added to facilitate the release of the nuclei and to obtain an ideal nuclear suspension; the sampling of young leaves gives an optimal number of intact nuclei, resulting in better fluorescence; and frequently replacing the scalpel blade reduces mechanical damage to the nuclei. Therefore, the protocol developed in this research can be used as a reference for ploidy and stability analysis in V. vinifera.

Molecular techniques, such as RAPD and microsatellite or ISSR, are valuable tools for analyzing the genetic fidelity of plants regenerated in vitro. Genetic profiles determined by DNA markers have shown that genetic fidelity is not compromised during somatic embryogenesis, except in very rare instances $[39,78]$. In our experimental system, even if a callus phase was observed during the incubation of explants, analysis with molecular markers (ISSR, SSR, and RAPD) indicated no differences between regenerants and mother plants, thus confirming previous studies on other species regenerated from flower-dissected explants $[50,79]$.

Since molecular marker profiles were monomorphic in all regenerants, we hypothesize that there was not a significant genome rearrangement after whole genome duplication. However, we observed that different ploidy levels induced several morphological changes of the shoots, mature leaves, and stomata in tetraploid regenerants. Alterations in leaf morphology, such as those present in our tetraploid regenerants, may enhance resistance to fungal pathogens. The stability of such changes along generations will be tested and favorable traits incorporated into an ongoing grape-breeding program at our institute.

\section{Conclusions}

This manuscript addresses the topic of alterations of the ploidy in grapevines regenerated in vitro. Nine percent of regenerants were tetraploid and showed profound anatomical/morphological changes in shoots, mature leaves, and stomata.

Supplementary Materials: The following are available online at https:/ / www.mdpi.com/article/10 $.3390 /$ cells10061336/s1, Table S1: RAPD, ISSR and SSR amplification profiles of in vitro propagated grapevine genotypes.

Author Contributions: C.C., L.A., A.C., R.D.L., A.P. and F.C. conceived and designed the experiments. C.C., L.A., A.M., D.C., F.C. and V.C. performed the experiments. F.C. prepared Figures 1-3. L.A., A.C., C.C. and F.C. supervised the experiments and wrote the manuscript. All authors discussed and interpreted results and read and approved the final manuscript. All authors have read and agreed to the published version of the manuscript.

Funding: This research was supported by Regione Siciliana (PSR Sicilia 2007-2013, Sottomisura 214/2A-Preservazione della biodiversità: Centri pubblici di conservazione, Grant No. 94750767637.

Institutional Review Board Statement: Not applicable.

Informed Consent Statement: Not applicable.

Data Availability Statement: Not applicable.

Acknowledgments: We are grateful to Roberto De Michele for helpful scientific discussion and critical reading of the manuscript.

Conflicts of Interest: The authors declare no conflict of interest. The founding sponsors had no role in the design of the study; in the collection, analyses, or interpretation of data; in the writing of the manuscript, and in the decision to publish the results. 


\section{References}

1. Wendel, J.F. Genome Evolution in Polyploids. In Plant Molecular Evolution; Doyle, J.J., Gaut, B.S., Eds.; Springer: Dordrecht, The Netherlands, 2000; pp. 225-249. [CrossRef]

2. Salman Rutland, C.A.; Hall, N.D.; McElroy, J.S. The Impact of Polyploidization on the Evolution of Weed Species: Historical Understanding and Current Limitations. Front. Agron. 2021, 3, 5. [CrossRef]

3. Salman-Minkov, A.; Sabath, N.; Mayrose, I. Whole-genome duplication as a key factor in crop domestication. Nat. Plants 2016, 2, 16115. [CrossRef]

4. Borrill, P.; Harrington, S.A.; Uauy, C. Genome-wide sequence and expression analysis of the NAC transcription factor family in polyploid wheat. G3 Genes Genomes Genet. 2017, 7, 3019-3029. [CrossRef]

5. Wei, T.; Wang, Y.; Xie, Z.; Guo, D.; Chen, C.; Fan, Q.; Deng, X.; Liu, J.-H. Enhanced ROS scavenging and sugar accumulation contribute to drought tolerance of naturally occurring autotetraploids in Poncirus trifoliata. Plant Biotechnol. J. 2019, 17, 1394-1407. [CrossRef]

6. Soltis, P.S.; Soltis, D.E. The role of genetic and genomic attributes in the success of polyploids. PNAS 2000, 97, 7051-7057. [CrossRef]

7. Iannicelli, J.; Guariniello, J.; Tossi, V.E.; Regalado, J.J.; Di Ciaccio, L.; van Baren, C.M.; Pitta Álvarez, S.I.; Escandon, A.S. The 'polyploid effect' in the breeding of aromatic and medicinal species. Sci. Hortic. 2020, 260, 108854. [CrossRef]

8. De Schepper, S.; Leus, L.; Eeckhaut, T.; Van Bockstaele, E.; Debergh, P.; De Loose, M. Somatic polyploid petals: Regeneration offers new roads for breeding Belgian pot azaleas. Plant Cell Tiss. Org. Cult. 2004, 76, 183-188. [CrossRef]

9. Leitch, A.R.; Leitch, I.J. Genomic plasticity and the diversity of polyploid plants. Science 2008, 320, 481-483. [CrossRef]

10. Sun, Q.; Sun, H.; Li, L.; Bell, R.L. In vitro colchicine-induced polyploid plantlet production and regeneration from leaf explants of the diploid pear (Pyrus communis L.) cultivar, 'Fertility'. J. Hortic. Sci. Biotechnol. 2009, 84, 548-552. [CrossRef]

11. Allario, T.; Brumos, J.; Colmenero-Flores, J.M.; Tadeo, F.; Froelicher, Y.; Talon, M.; Navarro, L.; Ollitrault, P.; Morillon, R. Large changes in anatomy and physiology between diploid Rangpur lime (Citrus limonia) and its autotetraploid are not associated with large changes in leaf gene expression. J. Exp. Bot. 2011, 62, 2507-2519. [CrossRef]

12. Van Laere, K.; França, S.C.; Vansteenkiste, H.; Van Huylenbroeck, J.; Steppe, K.; Van Labeke, M.C. Influence of ploidy level on morphology, growth and drought susceptibility in Spathiphyllum wallisii. Acta. Physiol. Plant. 2011, 33, 1149-1156. [CrossRef]

13. Tan, F.Q.; Tu, H.; Liang, W.J.; Long, J.M.; Wu, X.M.; Zhang, H.Y.; Guo, W.W. Comparative metabolic and transcriptional analysis of a doubled diploid and its diploid citrus rootstock (C. junos cv. Ziyang xiangcheng) suggests its potential value for stress resistance improvement. BMC Plant Biol. 2015, 15, 89. [CrossRef]

14. Doyle, J.J.; Coate, J.E. Polyploidy, the nucleotype, and novelty: The impact of genome doubling on the biology of the cell. Int. J. Plant Sci. 2019, 180, 1-52. [CrossRef]

15. Kim, E.D.; Chen, Z.J. Unstable transcripts in Arabidopsis allotetraploids are associated with non additive gene expression in response to abiotic and biotic stresses. PLoS ONE 2011, 6, e24251. [CrossRef]

16. Riddle, N.C.; Kato, A.; Birchler, J.A. Genetic variation for the response to ploidy change in Zea mays L. Theory Appl. Genet. 2006, 114, 101-111. [CrossRef] [PubMed]

17. Xiong, Y.C.; Li, F.M.; Zhang, T. Performance of wheat crops with different chromosome ploidy: Root-sourced signals, drought tolerance, and yield performance. Planta 2006, 224, 710-718. [CrossRef] [PubMed]

18. Xue, H.; Zhang, F.; Zhang, Z.H.; Fu, J.F.; Wang, F.; Zhang, B.; Ma, Y. Differences in salt tolerance between diploid and autotetraploid apple seedlings exposed to salt stress. Sci. Hortic. 2015, 190, 24-30. [CrossRef]

19. Zhang, F.; Xue, H.; Lu, X.; Zhang, B.; Wang, F.; Ma, Y.; Zhang, Z. Autotetraploidization enhances drought stress tolerance in two apple cultivars. Trees 2015, 29, 1773-1780. [CrossRef]

20. Sattler, M.C.; Carvalho, C.R.; Clarindo, W.R. The polyploidy and its key role in plant breeding. Planta 2016, 243, 281-296. [CrossRef]

21. Wei, T.; Wang, Y.; Liu, J.H. Comparative transcriptome analysis reveals synergistic and disparate defense pathways in the leaves and roots of trifoliate orange (Poncirus trifoliata) autotetraploids with enhanced salt tolerance. Hortic. Res. 2020, 7, 1-14. [CrossRef]

22. Marques, I.; Fernandes, I.; Paulo, O.S.; Lidon, F.C.; DaMatta, F.M.; Ramalho, J.C.; Ribeiro-Barros, A.I. A Transcriptomic Approach to Understanding the Combined Impacts of Supra-Optimal Temperatures and CO2 Revealed Different Responses in the Polyploid Coffea arabica and Its Diploid Progenitor, C. canephora. Int. J. Mol. Sci. 2021, 22, 3125. [CrossRef] [PubMed]

23. Carimi, F.; Pathirana, R.; Carra, A. Somatic Embryogenesis and Agrobacterium Mediated Genetic Transformation in Vitis. In Somatic Embryogenesis and Genetic Transformation in Plants; Aslam, J., Srivastava, P.S., Sharma, M.P., Eds.; Narosa Publishing House: New Delhi, India, 2013; pp. 179-218.

24. Larkin, P.J.; Scowcroft, W.R. Somaclonal variation-Anovel source of variability from cell cultures for plant improvement. Theory Appl. Genet. 1981, 60, 197-214. [CrossRef] [PubMed]

25. Vazquez, A.M.; Linacero, R. Stress and Somaclonal Variation. In Plant Developmental Biology: Biotechnological Perspectives; Pua, E.-C., Davey, M.R., Eds.; Springer: Heidelberg, The Netherlands, 2010; pp. 45-64. [CrossRef]

26. Endemann, M.; Hristoforoglu, K.; Stauber, T.; Wilhelm, E. Assessment of age-related polyploidy in Quercus robur L. somatic embryos and regenerated plants using DNA flow cytometry. Biol. Plant. 2002, 44, 339-345. [CrossRef] 
27. Cassells, A.C. Contamination Detection and Elimination. In Encyclopedia of Plant Cell Biology; Spier, R.E., Ed.; Wiley: Chichester, UK, 2000; pp. 577-586.

28. Carimi, F.; Pathirana, R.; Carra, A. Biotechnologies for Grapevine Germplasm Management and Improvement. In Grapevines: Varieties, Cultivation and Management; Szabo, P.V., Shojania, J., Eds.; Nova Science Publishers: New York, NY, USA, 2012; pp. 199-249.

29. Martinelli, L.; Gribaudo, I. Strategies for Effective Somatic Embryogenesis in Grapevine: An Appraisal. In Grapevine Molecular Physiology E Biotechnology, 2nd ed.; Roubelakis-Angelakis, K.A., Ed.; Springer: Dordrecht, The Netherlands, 2009 ; pp. 461-493.

30. Carimi, F.; Barizza, E.; Gardiman, M.; Lo Schiavo, F. Somatic embryogenesis from stigmas and styles of grapevine. Cell Dev. Biol. Plant 2005, 41, 249-252. [CrossRef]

31. Perrin, M.; Gertz, C.; Masson, J.E. High efficiency initiation of regenerable embryonic callus from anther filaments of 19-grapevine genotypes grown worldwide. Plant Sci. 2004, 167, 1343-1349. [CrossRef]

32. Gambino, G.; Ruffa, P.; Vallania, R.; Gribaudo, I. Somatic embryogenesis from whole flowers, anthers and ovaries of grapevine (Vitis spp). Plant Cell Tiss. Org. Cult. 2007, 90, 79-83. [CrossRef]

33. Maillot, P.; Kieffer, F.; Walter, B. Somatic embryogenesis from stem nodal sections of grapevine. Vitis 2006, 45, 185-189. [CrossRef]

34. Schellenbaum, P.; Mohler, V.; Wenzel, G.; Walter, B. Variation in DNA methylation patterns of grapevine somaclones (Vitis vinifera L.). BMC Plant Biol. 2008, 8, 78. [CrossRef]

35. Torregrosa, L.; Fernandez, L.; Bouquet, A.; Boursiquot, J.M.; Pelsy, F.; Martínez-Zapater, J.M. Origins and Consequences of Somatic Variation in Grapevine. In Genetics, Genomics, and Breeding of Grapes; Kole, C., Ed.; Science Publishers: Enfield, UK, 2011; pp. 68-92.

36. Leal, F.; Loureiro, J.; Rodriguez, E.; Pais, M.S.; Santos, C.; Pinto-Carnide, O. Nuclear DNA content of Vitis vinifera cultivars and ploidy level analyses of somatic embryo-derived plants obtained from anther culture. Plant Cell Rep. 2006, 25, 978-985. [CrossRef] [PubMed]

37. Acanda, Y.; Prado, M.J.; González, M.V.; Rey, M. Somatic embryogenesis from stamen filaments in grapevine (Vitis vinifera L. cv. Mencía): Changes in ploidy level and nuclear DNA content. Cell Dev. Biol. Plant 2013, 49, 276-284. [CrossRef]

38. Organisation Internationale de la Vigne et du Vin (OIV). Descriptor List for Grape Varieties and Vitis Species, 2nd ed.; Organisation Internationale de la Vigne et du Vin: Paris, France, 2009. Available online: http://www.oiv.int/oiv/info/enplubicationoiv (accessed on 15 January 2021).

39. Prado, M.J.; Rodriguez, E.; Rey, L.; González, M.V.; Santos, C.; Rey, M. Detection of somaclonal variants in somatic embryogenesisregenerated plants of Vitis vinifera by flow cytometry and microsatellite markers. Plant Cell Tiss. Org. Cult. 2010, 103, 49-59. [CrossRef]

40. Alvarez, M.E.; Nota, F.; Cabiagno, D.A. Epigenetic control of plant immunity. Mol. Plant Pathol. 2010, 11, 563-576. [CrossRef] [PubMed]

41. Raji, M.R.; Lotfi, M.; Tohidfar, M.; Zahedi, B.; Carra, A.; Abbate, L.; Carimi, F. Somatic embryogenesis of muskmelon (Cucumis melo L.) and genetic stability assessment of regenerants using flow cytometry and ISSR markers. Protoplasma 2018, 255, 873-883. [CrossRef] [PubMed]

42. Doležel, J. Applications of flow cytometry for the study of plant genomes. J. Appl. Genet. 1997, 3, 285-302. [CrossRef]

43. Loureiro, J.; Pinto, G.; Lopes, T.; Doležel, J.; Santos, C. Assessment of ploidy stability of the somatic embryogenesis process in Quercus suber L. using flow cytometry. Planta 2005, 221, 815-822. [CrossRef]

44. Doležel, J. Flow cytometric analysis of nuclear DNA content in higher plants. Phytochem. Anal. 1991, 2, 143-154. [CrossRef]

45. Carimi, F.; Mercati, F.; Abbate, L.; Sunseri, F. Microsatellite analyses for evaluation of genetic diversity among Sicilian grapevine cultivars. Genet. Resour. Crop Evol. 2010, 57, 703-719. [CrossRef]

46. Carimi, F.; Mercati, F.; De Michele, R.; Fiore, M.C.; Riccardi, P.; Sunseri, F. Intravarietal genetic diversity of the grapevine (Vitis vinifera L.) cultivar 'Nero d'Avola' as revealed by microsatellite markers. Genet. Resour. Crop Evol. 2011, 58, 967-975. [CrossRef]

47. Murashige, T.; Skoog, F. A revised medium for rapid growth and bioassays with tobacco tissue cultures. Physiol. Plant. 1962, 15, 473-479. [CrossRef]

48. Carra, A.; Sajeva, M.; Abbate, L.; Siragusa, M.; Pathirana, R.; Carimi, F. Factors affecting somatic embryogenesis in eight Italian grapevine cultivars and the genetic stability of embryo-derived regenerants as assessed by molecular markers. Sci. Hortic. 2016, 204, 123-127. [CrossRef]

49. Oddo, E.; Abbate, L.; Inzerillo, S.; Carimi, F.; Motisi, A.; Sajeva, M.; Nardini, A. Water relations of two Sicilian grapevine cultivars in response to potassium availability and drought stress. Plant Physiol. Biochem. 2020, 148, 282-290. [CrossRef] [PubMed]

50. Carra, A.; Sajeva, M.; Abbate, L.; Siragusa, M.; Sottile, F.; Carimi, F. In vitro plant regeneration of caper (Capparis spinosa L.) from floral explants and genetic stability of regenerants. Plant Cell Tis. Org. Cult. 2012, 109, 373-381. [CrossRef]

51. Otto, F.J. Preparation and Staining of Cells for High-Resolution DNA Analysis. In A Flow Cytometry and Cell Sorting; Radbruch, A., Ed.; Springer: Berlin/Heidelberg, Germany, 1992; pp. 65-68.

52. Praça-Fontes, M.M.; Carvalho, C.R.; Clarindo, W.R.; Cruz, C.D. Revisiting the DNA C-values of the genome size-standards used in plant flow cytometry to choose the 'best primary standards'. Plant Cell Rep. 2011, 30, 1183-1191. [CrossRef] [PubMed]

53. Doyle, J.J.; Doyle, J.L. A rapid DNA isolation procedure from small quantities of fresh leaf tissue. Phytochem. Bull. 1987, 19, 11-15.

54. Gristina, A.S.; Fici, S.; Siragusa, M.; Fontana, I.; Garfi, G.; Carimi, F. Hybridization in Capparis spinosa L.: Molecular and morphological evidence from a Mediterranean island complex. Flora 2014, 209, 733-741. [CrossRef] 
55. Siragusa, M.; Carra, A.; Salvia, L.; Puglia, A.M.; De Pasquale, F.; Carimi, F. Genetic instability in calamondin (Citrus madurensis Lour.) plants derived from somatic embryogenesis induced by diphenylurea derivatives. Plant Cell Rep. 2007, 26, 1289-1296. [CrossRef]

56. Meziane, M.; Frasheri, D.; Carra, A.; Boudjeniba, M.; D’Onghia, A.M.; Mercati, F.; Djelouah, K.; Carimi, F. Attempts to eradicate graft-transmissible infections through somatic embryogenesis in Citrus ssp. and analysis of genetic stability of regenerated plants. Eur. J. Plant Pathol. 2016, 10, 1-11. [CrossRef]

57. Haddad, B.; Carra, A.; Saadi, A.; Haddad, N.; Mercati, F.; Gristina, A.S.; Boukhalfa, S.; Djillali, D.; Carimi, F. In vitro propagation of the relict Laperinne's olive (Olea europaea L. subsp. laperrinei). Plant Biosyst. 2018, 152, 621-630. [CrossRef]

58. De Michele, R.; La Bella, F.; Gristina, A.S.; Fontana, I.; Pacifico, D.; Garfi, G.; Motisi, A.; Crucitti, D.; Abbate, L.; Carimi, F. Phylogenetic Relationship Among Wild and Cultivated Grapevine in Sicily: A Hotspot in the Middle of the Mediterranean Basin. Front. Plant Sci. 2019, 10, 1506. [CrossRef]

59. Salisbury, E.J. On the causes and ecological significance of stomatal frequency, with special reference to the woodland flora. Philos. Trans. R. Soc. Lond. Ser. B 1928, 216, 1-65. [CrossRef]

60. Dhooghe, E.; Van Laere, K.; Eeckhaut, T.; Leus, L.; Van Huylenbroeck, J. Mitotic chromosome doubling of plant tissues in vitro. Plant Cell Tiss. Org. Cult. 2011, 104, 359-373. [CrossRef]

61. Levin, D.A. Polyploidy and novelty in flowering plants. Am. Nat. 1983, 122, 1-25. [CrossRef]

62. Estilai, A.; Shannon, M.C. Salt Tolerance in Relation to Ploidy Level in Guayule. In New Crops; Janick, J., Simon, J.E., Eds.; Wiley: New York, NY, USA, 1993; pp. 349-351.

63. Remotti, P.C. Primary and secondary embryogenesis from cell suspension cultures of Gladiolus. Plant Sci. 1995, 107, 205-214. [CrossRef]

64. Brar, D.S.; Jain, S.M. Somaclonal Variation: Mechanism and Applications in Crop Improvement. In Current Plant Science and Biotechnology in Agriculture; Jain, S.M., Brar, D.S., Ahloowalia, B.S., Eds.; Springer: Dordrecht, The Netherlands, 1998 ; pp. 15-37. [CrossRef]

65. Diaz-Sala, C.; Rey, M.; Boronat, A.; Besford, R.; Rodriguez, R. Variations in the DNA methylation and polypeptide patterns of adult hazel (Corylus avellana L.) associated with sequential in vitro subcultures. Plant Cell Rep. 1995, 15, 218-221. [CrossRef]

66. Rakoczy-Trojanowska, M. The effects of growth regulators on somaclonal variation in rye (Secale cereale L.) and selection of somaclonal variants with increased agronomic traits. Cell Mol. Biol. Lett. 2002, 7, 1111-1120. [PubMed]

67. Haoa, Y.J.; Wen, X.P.; Deng, X.X. Genetic and epigenetic evaluations of citrus calluses recovered from slow-growth culture. J. Plant Physiol. 2004, 16, 479-484. [CrossRef] [PubMed]

68. Jaligot, E.; Beulé, T.; Baurens, F.C.; Billotte, N.; Rival, A. Search for methylation-sensitive amplification polymorphisms associated with the 'mantled' variant phenotype in oil palm (Elaeis guineensis Jacq.). Genome 2004, 47, 224-228. [CrossRef] [PubMed]

69. Sharma, S.K.; Bryan, G.J.; Winfield, M.O.; Millam, S. Stability of potato (Solanum tuberosum L.) plants regenerated via somatic embryos, axillary bud proliferated shoots, microtubers and true potato seeds: A comparative phenotypic, cytogenetic and molecular assessment. Planta 2007, 226, 1449-1458. [CrossRef]

70. Menéndez-Yuffá, A.; Barry-Etienne, D.B. , Georget, F.; Etienne, H. A comparative analysis of the development and quality of nursery plants derived from somatic embryogenesis and from seedlings for large-scale propagation of coffee (Coffea arabica L.). Plant Cell Tiss. Org. Cult. 2010, 102, 297-307. [CrossRef]

71. Leva, A.R.; Petruccelli, R.; Rinaldi, L.M.R. Somaclonal Variation in Tissue Culture: A Case Study with Olive. In Recent Advances in Plant in vitro Culture; Leva, A.R., Rinaldi, L.M.R., Eds.; Intech Open Access Publisher: Croatia, Hungary, 2012 ; pp. 123-150.

72. Manchanda, P.; Kaur, A.; Gosal, S.S. Somaclonal Variation for Sugar Cane Improvement. In Biotechnologies of Crop Improvement; Gosal, S., Wani, S., Eds.; Springer: Cham, Switzerland, 2018; pp. 299-326.

73. Dalla Costa, L.; Malnoy, M.; Gribaudo, I. Breeding next generation tree fruits: Technical and legal challenges. Hortic. Res. 2017, 4, 17067. [CrossRef]

74. Desperrier, J.C.; Berger, J.L.; Bessis, R.; Fournioux, J.C.; Labroche, C. Création clonale dirigée par embryogenèse somatique. Bullettin de l'O.I.V. 2003, 76, 751-765.

75. Boso, S.; Alonso-Villaverde, V.; Santiago, J.L.; Gago, P.; Dürrenberger, M.; Düggelin, M.; Kassemeyer, H.H.; Martinez, M.C. Macroand microscopic leaf characteristics of six grapevine genotypes (Vitis spp.) with different susceptibilities to grapevine downy mildew. Vitis 2010, 49, 43-50. [CrossRef]

76. Muganu, M.; Paolocci, M. Adaptation of Local Grapevine Germplasm: Exploitation of Natural Defence Mechanisms to Biotic Stresses. In The Mediterranean Genetic Code—Grapevine and Olive; Poljuha, D., Sladonja, B., Eds.; Intech Open Access Publisher: London, UK, 2013; pp. 221-246.

77. Leroy, X.J.; Leon, K.; Branchard, M. IRSS and somaclonal variation: A new molecular technique for an important in vitro phenomenon. Electron. J. Biotech. 2000, 3, 1-2.

78. Yang, X.M.; Cao, Z.Y.; An, L.Z.; Wang, Y.M.; Fang, X.W. In vitro tetraploid induction via colchicine treatment from diploid somatic embryos in grapevine (Vitis vinifera L.). Euphytica 2006, 152, 217. [CrossRef]

79. Seguí-Simarro, J.M.; Nuez, F. Embryogenesis induction, callogenesis, and plant regeneration by in vitro culture of tomato isolated microspores and whole anthers. J. Exp. Bot. 2007, 58, 1119-1132. [CrossRef] [PubMed] 